\title{
A Questionnaire Analysis on the Status Quo of Contemporary College Students' Ideological and Political Quality
}

\author{
Xiaokui Wang \\ Sichuan University of Arts and Science, Dazhou, China \\ Email: P119800710@163.com
}

How to cite this paper: Wang, $\mathrm{X}$. K. (2020). A Questionnaire Analysis on the Status Quo of Contemporary College Students' Ideological and Political Quality. Open Journal of Social Sciences, 8, 207-220. https://doi.org/10.4236/jss.2020.89015

Received: August 19, 2020

Accepted: September 21, 2020

Published: September 24, 2020

Copyright $\odot 2020$ by author(s) and Scientific Research Publishing Inc. This work is licensed under the Creative Commons Attribution International License (CC BY 4.0).

http://creativecommons.org/licenses/by/4.0/

\section{(c) (i) Open Access}

\begin{abstract}
This article compiles a questionnaire from the three dimensions of "political literacy", "ideological ethics" and "mental health". The survey finds that the university is living in the problems of large individual differences in political literacy, individual ideological and moral flaws, and low levels of mental health. The author proposes that in terms of concepts, the intensity of education in the critical period of ideological and political education for college students should be increased; in terms of ways, the educational function of ideological and political courses and the ideological and political theories teaching in all courses need to be integrated; in terms of content, the life and context of ideological and political education content should be promoted; in terms of methods, a diversified strategy system of ideological and political education that is experiential, verification, and generative should be adopted.
\end{abstract}

\section{Keywords}

College Students, Ideology and Politics, Quality

\section{Introduction}

Who to train and how to train them is a fundamental issue that must be resolved in our country's college education. Studying and mastering the ideological and political quality of contemporary college students, and earnestly strengthening and improving the ideological and political education of college students, will directly affect the physical and mental health of college students, whether the socialist cause of our country will succeed and have a long-lasting foundation, the peaceful rise and great rejuvenation of the Chinese nation. This article, taking three universities as examples, with the development of the ideological and po- 
litical quality of college students as the starting point, compiles a questionnaire to investigate the current status of the ideological and political quality of college students, reveals existing problems, and proposes countermeasures to improve the ideological and political quality of contemporary college students.

\section{Compilation and Testing of the Questionnaire}

\subsection{Preparation of the Preliminary Test Questionnaire}

The Education Law stipulates that the state shall educate the educated in patriotism, collectivism, and socialism, as well as education in ideals, ethics, discipline, legal system, national defense, and national unity. Education should inherit and carry forward the excellent historical and cultural traditions of the Chinese nation and absorb all the outstanding achievements of the development of human civilization. These are the main contents of ideological and political education. First, the research selected items from some mature scales related to the topics of "college students", "ideological politics", and "mental health". These items mainly constitute part of the items in dimension one "political literacy" and dimension three "mental health". Secondly, following the connotation of "ideological and political education", that is, ideological and political education is the use of certain ideological concepts, political views, and ethical norms by society or social groups to exert purposefully, planned and organized influence on its members so that they can form social practice activities that meet the ideological and moral requirements of a certain society, it sorted out the three sub-dimensions of "political identity", "ethics", and "ideological concept". Then, through open interviews with a random sample of college students, it sought to understand the moral qualities most valued by college students, their understanding of China's political system and basic national conditions, and the development of mental health, and sorted out the high-frequency issues in the interviews and formed part of the items. Finally, the summary is carried out and questionnaires were formed by merging similar items, removing the items that are too individualized. There are 31 items in total, including four dimensions, and each dimension consists of 8 questions.

After the original questionnaire is completed, first, five relevant experts were asked to read each item according to the following requirements: 1) Whether there are items with unclear semantics; 2) Whether there are items that are difficult to judge; 3 ) Whether there are items that should be added or deleted, mark the items and sentences that have the above problems, and modify the items accordingly. Secondly, six relevant experts were invited to rate the content of each item (referring to whether the item described accurately reflects the characteristics of the questionnaire and the dimension where it is located) and expression (referring to whether the textual expression of the meaning of the item is easy to understand), give marks, and suggest amendments. Finally, based on the opinions of the above-mentioned experts, the questionnaire was revised from the three aspects of its conformity with ideological and political literacy, the reada- 
bility of the items, and the scientific nature of the questionnaire, and finally the preliminary test questionnaire was formed. The initial test questionnaire deleted a slightly repetitive dimension and some unclear or content-sensitive items. The initial test questionnaire deleted a slightly repetitive dimension and some unclear or content-sensitive items. In the end, 22 questions were left, involving three dimensions, of which dimension one was "political quality" with 8 questions and dimension two "ideology and morality" with 8 questions and Dimension 3 "Mental Health" 6 questions. All questions are scored according to 1 - 4 Likert scale.

\subsection{Test of the Initial Test Questionnaire}

The questionnaire is a computer test, using the "questionnaire star" program under a unified instruction to conduct a unified test. The measurement tools are incorporated into the questionnaire along with the demographic items. The test time is 10 minutes. The test results are submitted on the spot and uploaded to the back-end management office. The data obtained is registered by the questionnaire. Taking a convenient sampling method, questionnaires were distributed in the three sample universities, and invalid data with a response time of less than 120 seconds were eliminated. A total of 5,824 valid questionnaires were collected and finally imported into the SPSS social science statistical software for analysis.

1) The concordant coefficient

As shown in Table 1 , the reliability of this questionnaire is 0.538 , which is good.

2) Project Analysis

Critical ration (CR value) and correlation analysis between items and total score as a reference indicator were used for the discrimination of items in the preliminary questionnaire. According to the calculation method of the critical ratio method, the total scores of the questionnaires were sorted in the order of high and low. The top $27 \%$ of the participants were divided into high groups, and the last $27 \%$ of the participants were divided into low groups. The independent sample t-test was used to test each item. The difference in score was tested for significance, and the items that have not reached the significance level were deleted. The results show that the CR values of 22 items are all between 10.16 and 31.64, reaching a significant level, and the items have a good degree of discrimination.

3) Correlation analysis

It is generally believed that the correlation between items and the total score must not only be significant, but also show a medium-to-high relationship, that

Table 1. The concordant coefficient.

\begin{tabular}{ccc}
\hline Cronbach's Alpha & Cronbach's Alpha based on the standardization project & Number of items \\
\hline 0.552 & 0.538 & 22 \\
\hline
\end{tabular}


is, the correlation coefficient must be at least 0.4 . Therefore, according to the standard of correlation coefficient greater than 0.4 , items that do not reach the title were eliminated.

The results show that each item has reached a significant level, and the correlation coefficients with the total score are all above 0.4. Therefore, all 22 items can be reserved. See Table 2 for details.

Based on the results of the analysis of the two items, the 56 items in the questionnaire have a high degree of discrimination and can be retained.

4) Factor analysis

Principal component analysis method and maximum variance method were used for exploratory factor analysis of 22 items. The correlation between variables used Bartlett's sphere test, and the KMO coefficient determined whether it is significant. It is also generally admitted that a KMO coefficient above 0.90 is very suitable for factor analysis, while a coefficient below 0.6 is not suitable for factor analysis. According to the results of exploratory factor analysis, the KMO coefficient of the questionnaire is 0.724 , and the Bartlett sphere test is significant, indicating that the questionnaire is suitable for further exploratory factor analysis (Table 3).

The questionnaire was processed by dimensionality reduction and common factors were extracted. The result is shown in Figure 1. Through the characteristic

Table 2. Item analysis results of the preliminary questionnaire.

\begin{tabular}{cccccc}
\hline Item & CR value & Total Relevance & Item & CR Value & Total Relevance \\
\hline $\mathrm{t} 1$ & 14.48 & $0.55^{* *}$ & $\mathrm{t} 12$ & 14.94 & $0.46^{*}$ \\
$\mathrm{t} 2$ & 15.27 & $0.67^{*}$ & $\mathrm{t} 13$ & 29.75 & $0.72^{\star}$ \\
$\mathrm{t} 3$ & 22.54 & $0.46^{* *}$ & $\mathrm{t} 14$ & 20.13 & $0.66^{* *}$ \\
$\mathrm{t} 4$ & 21.32 & $0.73^{*}$ & $\mathrm{t} 15$ & 12.58 & $0.64^{* *}$ \\
$\mathrm{t} 5$ & 17.38 & $0.39^{*}$ & $\mathrm{t} 16$ & 30.29 & $0.53^{* *}$ \\
$\mathrm{t} 6$ & 19.04 & $0.48^{\star}$ & $\mathrm{t} 17$ & 27.22 & $0.72^{\star}$ \\
$\mathrm{t} 7$ & 10.16 & $0.52^{* *}$ & $\mathrm{t} 18$ & 16.94 & $0.79^{\star}$ \\
$\mathrm{t} 8$ & 25.14 & $0.41^{* *}$ & $\mathrm{t} 19$ & 31.64 & $0.47^{* *}$ \\
$\mathrm{t} 9$ & 11.38 & $0.57^{\star}$ & $\mathrm{t} 20$ & 19.08 & $0.53^{\star}$ \\
$\mathrm{t} 10$ & 17.51 & $0.55^{* *}$ & $\mathrm{t} 21$ & 16.37 & $0.72^{\star}$ \\
$\mathrm{t} 11$ & 26.24 & $0.69^{* *}$ & $\mathrm{t} 22$ & 23.06 & $0.43^{* *}$ \\
\hline
\end{tabular}

${ }^{*} p<0.05,{ }^{* *} p<0.01$.

Table 3. KMO and Bartlett test.

\begin{tabular}{ccc}
\hline \multicolumn{2}{c}{ Kaiser-Meyer-Olkin Measure of Sampling Adequacy } & 0.724 \\
\hline \multirow{2}{*}{ Bartlett's Test of Sphericity } & Approx. Chi-Square & $219,427.459$ \\
& df & 8532 \\
& Sig. & 0.000 \\
\hline
\end{tabular}




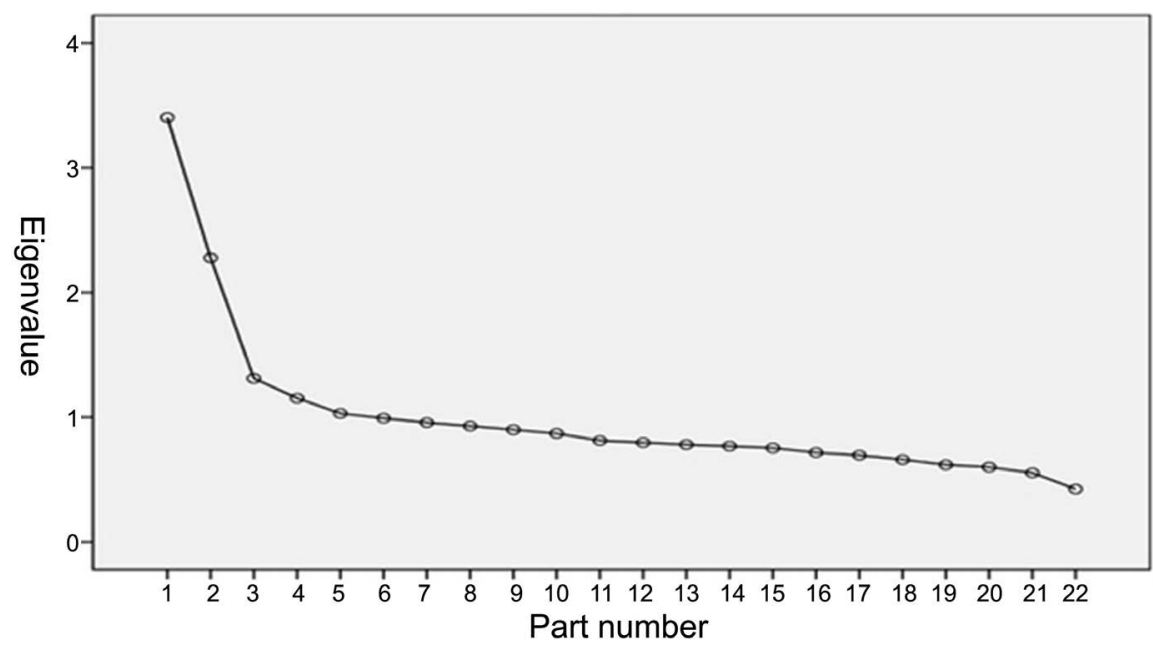

Figure 1. Scree plot.

curve of the scree pot, it can be seen that a total of 3 common factors have been extracted, and the characteristic value curve of the subsequent factors tends to be flat, so the three dimensions in the questionnaire initially conform to the theoretical conception and have good structural validity.

Putting all the items on the contribution value of the three dimensions, it can be observed that (Table 4) items 5, 6, 8, 9, 12, 16, 19, 20, 21 are in the same dimension; items $1,2,3,4,7,13,14$, and 15 belong to the same dimension; item $10,11,17,18$, and 22 belong to the same dimension. There is a certain difference from the previous theoretical conception, but overall the structure validity is good, and the three dimensions can explain 59.3\% of the variance of the result.

To sum up, this reliability and validity test has passed the preliminary test, and there are two main problems: First, some items such as item 10, item 21 and item 22 do not contribute much in the three dimensions and can be appropriately modified; second, although the questionnaire analysis results show that the questionnaire also has three dimensions, it does not conform to the previous theoretical conception, and the attribution of the items and dimensions needs to be adjusted.

\section{Analysis of Questionnaire Results}

\subsection{General Overview}

To arrange the total scores obtained by everyone in this questionnaire, as shown in Figure 2, it shows an obvious normal distribution trend. The lowest and highest scores are relatively small, and there are more scores in the middle. The lowest score is 25 . The highest score is 85 points, and most people score between 60 and 65 . The differences in grade and gender were tested, and no significant differences were found in the total score and the sub-scores of the three dimensions.

As shown in Table 5, among the students who participated in fulfilling the questionnaire, male students accounted for $18.44 \%$ and female students accounted 
Table 4. Component matrix.

\begin{tabular}{|c|c|c|c|}
\hline & \multicolumn{3}{|c|}{ Component } \\
\hline & 1 & 2 & 3 \\
\hline Q1 & -0.065 & 0.662 & -0.101 \\
\hline Q2 & 0.027 & 0.259 & 0.151 \\
\hline Q3 & -0.177 & 0.611 & -0.063 \\
\hline Q4 & -0.037 & 0.281 & -0.008 \\
\hline Q5 & 0.678 & 0.125 & -0.187 \\
\hline Q6 & 0.660 & 0.258 & -0.242 \\
\hline Q7 & -0.487 & 0.467 & 0.012 \\
\hline Q8 & 0.506 & -0.066 & 0.160 \\
\hline Q9 & 0.383 & 0.198 & 0.265 \\
\hline Q10 & 0.346 & -0.196 & 0.357 \\
\hline Q11 & -0.473 & 0.161 & 0.323 \\
\hline Q12 & 0.533 & 0.189 & -0.002 \\
\hline Q13 & -0.159 & 0.598 & -0.113 \\
\hline Q14 & -0.425 & 0.287 & 0.095 \\
\hline Q15 & -0.161 & 0.414 & -0.108 \\
\hline Q16 & 0.633 & 0.246 & -0.226 \\
\hline Q17 & 0.164 & 0.140 & 0.581 \\
\hline Q18 & 0.178 & 0.140 & 0.567 \\
\hline Q19 & 0.381 & 0.282 & 0.170 \\
\hline Q20 & 0.529 & 0.212 & 0.008 \\
\hline Q21 & 0.285 & 0.005 & 0.072 \\
\hline Q22 & -0.068 & 0.197 & 0.273 \\
\hline
\end{tabular}

Extraction method: main component analysis. a. Extract 3 components.

Table 5. Distribution of demographic variables $(n=5824)$.

\begin{tabular}{|c|c|c|c|}
\hline & & Number & Percentage \\
\hline \multirow[t]{3}{*}{ Gender } & Male & 1074 & $18.44 \%$ \\
\hline & Female & 4750 & $81.56 \%$ \\
\hline & Freshmen & 3320 & $57 \%$ \\
\hline \multirow{3}{*}{ Year } & Sophomore & 1481 & $25.43 \%$ \\
\hline & Junior & 732 & $12.57 \%$ \\
\hline & Senior & 291 & $0.5 \%$ \\
\hline \multirow{4}{*}{ Major } & Philosophy, economics, law management, etc. & 1879 & $32.27 \%$ \\
\hline & Education, literature, history, etc. & 1570 & $26.96 \%$ \\
\hline & Science, engineering, agriculture, medicine, etc. & 1268 & $21.77 \%$ \\
\hline & Art, military, etc. & 1107 & $19 \%$ \\
\hline
\end{tabular}




\section{Test score distribution chart}

Number of answers:5824

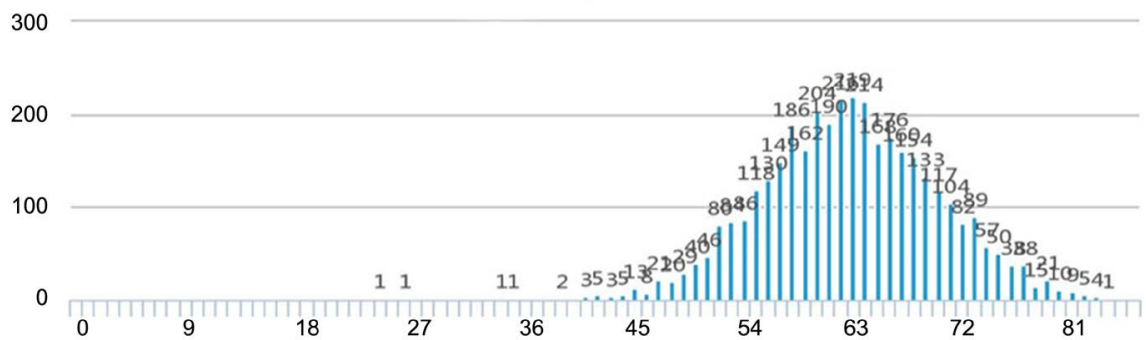

Figure 2. Score distribution.

for $81.56 \%$. From the distribution of grades, freshman students accounted for the most, accounting for $57.00 \%$ of the total number of students, and senior students were the least, only accounting for $0.5 \%$ of the total number of students; from the perspective of majors, the distribution of various majors is relatively even. The students majoring in "science, engineering, agriculture, and medicine" are the most, accounting for $32.27 \%$ of the total number, followed by "pedagogy", literature" and "history", accounting for $26.96 \%$ of the total.

\subsection{Dimensional Analysis}

1) Dimensional analysis of political literacy

Designed according to the original dimensions of the questionnaire, the descriptive statistical results of political literacy are shown in Table 6. It can be seen that the mean value of the total political literacy score is 20.28 , and the score rate is $63.382 \%$, indicating that the students of the three sample universities have better political literacy. The standard deviation of the total score reached 8.729, and the degree of dispersion of the data is very large, revealing that there are large differences between individuals in this dimension.

Among them, the average value of "Item 1" is 3.63, which shows that the students have a deep understanding of "a society under the rule of law" and have a very high agreement with "There are laws to follow, law enforcement must be strict, and violations must be investigated". The lowest average value of "item 8 " is only 1.42 , indicating that if students find that teachers or student cadres are using power for personal gain and corruption, few people dare to stand up and report them, but choose silence and connivance. The variance of "item 4" is the largest, reaching 1.76 . There is only one correct answer to this question, with an average of 2.61, indicating that nearly half of the students answered incorrectly. They don't know enough about what is "the soul of rejuvenation", and only $41 \%$ of the students' answers to the "core values of socialism" were correct.

2) Analysis of ideological and moral dimensions

The descriptive statistical results of ideology and ethics are shown in Table 7. It can be seen that the mean value of the ideology and ethics total score is 19.81, and the score rate is $62.81 \%$, indicating that the students of the three sample 
Table 6. Mean values of political literacy scores.

\begin{tabular}{cccc}
\hline & $\mathrm{N}$ & Average & Sd. \\
\hline Q1 & 5824 & 3.6333 & 0.746 \\
Q2 & 5824 & 1.7955 & 0.520 \\
Q3 & 5824 & 3.2173 & 0.527 \\
Q4 & 5824 & 2.597 & 1.761 \\
Q5 & 5824 & 1.5412 & 0.528 \\
Q6 & 5824 & 2.0226 & 0.593 \\
Q7 & 5824 & 3.0606 & 0.809 \\
Q8 & 5824 & 1.42 & 0.602 \\
Political quality & 5824 & 20.28 & 8.729 \\
Effective N (listwise) & 5824 & & \\
\hline
\end{tabular}

Table 7. Mean ideological and moral scores.

\begin{tabular}{cccc}
\hline & $\mathrm{N}$ & Average & Sd. \\
\hline Q9 & 5824 & 2.0962 & 0.558 \\
Q11 & 5824 & 3.1249 & 0.217 \\
Q12 & 5824 & 2.3375 & 0.923 \\
Q13 & 5824 & 2.2113 & 0.803 \\
Q14 & 5824 & 3.3675 & 0.808 \\
Q15 & 5824 & 2.7465 & 1.254 \\
Q16 & 5824 & 2.6369 & 0.799 \\
Ideology and ethics & 5824 & 2.2991 & 0.764 \\
Effective N (listwise) & 5824 & 19.8198 & 7.296 \\
\hline
\end{tabular}

universities have good ideological and ethical standards, with a standard deviation of 7.30. The degree of dispersion of the data is slightly larger, and the individual scores in this dimension have smaller differences than political qualities.

Among them, the average value of "Item 13" is 3.37, which shows that the students have the spirit of picking up money, and they will choose to return unconditionally when they find the lost property of others. The lowest average of "Item 9" is 2.1 , which shows that students have different understandings and opinions on the phenomenon of "Sugar Daddy". The variance of "Item 14" is the largest, reaching 1.25. This question examines whether students have plagiarized or cheating ideas and behaviors. A large variance indicates that there are large differences between individuals, indicating that students are plagiarizing or cheating. The situation is polarized.

3) Dimensional analysis of mental health

The descriptive statistical results of mental health are shown in Table 8. It can 
Table 8. Mean mental health scores.

\begin{tabular}{cccc}
\hline & $\mathrm{N}$ & Average & Sd. \\
\hline Q17 & 5824 & 2.1459 & 1.184 \\
Q18 & 5824 & 1.9109 & 1.194 \\
Q19 & 5824 & 2.8872 & 1.260 \\
Q20 & 5824 & 2.1941 & 0.500 \\
Q21 & 5824 & 1.7174 & 0.719 \\
Q22 & 5824 & 2.1889 & 0.827 \\
Mental Health & 5824 & 15.678 & 7.4872 \\
Effective N (listwise) & 5824 & & \\
\hline
\end{tabular}

be seen that the mean value of the total mental health score is 15.68 , and the score rate is $65.33 \%$, indicating that the mental health of the students in the three sample colleges is relatively good, and the standard deviation of the total score is 7.49 , with a slightly larger degree of dispersion of the data, indicating that the level of students' mental health is also quite different.

Among them, the highest average value of "Item 19" was 2.89, indicating that students generally choose to talk to relatives and friends when encountering difficulties and setbacks, and less choose to digest and seek help from psychological counseling. The lowest average value of "Item 21 " was only 1.72 , indicating that the students' sleep condition in the past month was worrying. Most people thought that they often went to bed late, and their muscles were sore and tired when they woke up. This result may also be due to the end of the data collection period, and the students are busy staying up late to review their homework.

\subsection{Result Analysis}

1) In terms of political literacy, individual differences are large

Through the investigation, it can be found that the students of the three sample universities have high political literacy and have a clear understanding of the key to the society ruled by law: "There are laws to follow, law enforcement must be strict, and violations of the law must be investigated"; a clear notion of the relationship between personal interests and national interests, and they have a certain sense of protection for China's intangible cultural heritage, pay more attention to current issues at home and abroad, as well as the formulation and promulgation of China's laws and regulations, and fully affirm the educational significance of the life of the university student league. However, the understanding of the core values of socialism needs to be further strengthened, and there are large differences between individuals in terms of political literacy.

2) In terms of moral, individual students have flaws

The life values of college students in the three sample universities are generally positive-they are fair, just, honest and trustworthy. For example, $98 \%$ of the students disagree with the behavior of "sugar daddy" in society, and they would 
not choose to do so; most of the students believe that they are honest and they have the awareness of collecting money and caring for the environment. However, the communication with the teacher after class was insufficient. When it comes to participation in volunteer service and cheating in exams, the survey results are still not satisfactory. The specific manifestation is that some students frankly admit that they have cheated on exams and copied classmates' homework. The number of their participating in volunteer services is also relatively small.

3) In terms of mental health, some students have lower levels

In terms of mental health, the overall mental health of students in the three sample universities is relatively good, but the individual differences are large. There are various sources of stress in college life. About $39 \%$ of students feel that the most is academic pressure, followed by employment pressure, and the attribution of pressure is mainly due to the fact that "there is no effective learning method". The coping style in the face of troubles is also not ideal. Some students choose to talk to classmates and friends, and some choose to think and digest on their own. Few would ask for help from the teacher or counselor. In terms of sleep emotional status, nearly half of the students said that their sleep conditions were not satisfactory, more than $20 \%$ felt irritable and anxious, and $10 \%$ felt listless and depressed. All in all, the mental health of college students is relatively satisfying, but some students with low mental health are worthy of attention.

\section{Constructing an Educational Strategy System for the Development of Ideological and Political Quality of College Students}

Considering the above problems and their attributions, the improvement of current college students' ideological and political quality requires overall consideration, distributed implementation, and systematic promotion. From the perspective of ideological and political education in colleges and universities, it is necessary to integrate multi-dimensional considerations in educational awareness, educational approaches, content, methods, and management to form an educational strategy system for the development of college students' ideological and political quality.

\subsection{Enhance the Awareness of Ideological and Political Education, and Increase the Intensity of Education during the Critical Period of Ideological and Political Education for College Students}

Ideological and political education involves the party for which students are educated, and its importance is self-evident. Undergraduates are in a critical period of ideological and political education at the university level, and it is most imperative and meaningful to improve their ideological and political quality. However, how to increase the importance of ideological and political education for college students, deeply grasp the characteristics and regularity of the devel- 
opment of ideological and political quality of college students, and increase the intensity of the critical period of ideological and political education requires the formation of a set of practical mechanisms. The specific measures are mainly in two aspects:

On the one hand, a special leadership organization should be set up to strengthen awareness and share responsibilities. The school has established a leading group office for the ideological and political education of college students. The main leaders of the school assume the main responsibilities, personally grasp and promote the implementation, and other leaders of the school should also pay attention to it as a major part of their respective management work.

On the other hand, we should establish and implement the promotion and evaluation methods of college students' ideological and political education and form a normal work and long-term mechanism for the implementation of college students' ideological and political education.

\subsection{Optimize the Ideological and Political Education of College Students, and Integrate the Educational Function of Ideological and Political Courses and the Ideological and Political Theories Teaching in All Courses}

The "Three Comprehensive" is the basic way of ideological and political education for college students. It is also a new exploration of the characteristics and laws of ideological and political education in colleges and universities in the new era. It requires colleges and universities to educate people, educate people in the whole process, and educate people in an all-round way, and lead ideological values throughout the whole process and all links of education and teaching. It requires to further improve the talent training ability, innovative talent training model, and cultivate top-notch innovative talents (Huang, 2020). How to optimize the three-dimensional education approach? This is an important realistic topic for improving the effectiveness of ideological and political education. In view of the actual situation, the main suggestions are: to enhance the awareness of ideological and political education of all employees, and implement educational responsibilities; to base on the development of college students with the whole process runs through ideological and political education and grasp the main nodes of the education process, key growth events with links and standards; radiate the influence of ideological and political education in all directions and throughout the time span of students' college education and leave no dead ends in this respect.

Among them, classroom teaching is the main position of ideological and political education for college students, and ideological and political courses and ideological and political theories teaching in all courses are the specific aspects of three-dimensional education. It is necessary to bring into play the main channel of positive education of ideological and political courses and the integrated education of curriculum ideological and political disciplines. General Secretary Xi 
Jinping emphasized at the National Conference on Ideological and Political Work in Colleges and Universities that the ideological and political theory courses should be strengthened in improvement, enhance the affinity and pertinence of ideological and political education, and meet the needs and expectations of students' growth and development. This further clarifies the goal and direction of the teaching reform of ideological and political theory courses. To this end, on the one hand, it is necessary to strengthen the subject teaching research of ideological and political course teachers, including studying the state, learning ability and learning effect of students on ideological and political courses, and then reflect and optimize the teaching methods of ideological and political courses, continuously improve the scientific, ideological, and pertinent teaching methods and enhance the effectiveness of teaching; on the other hand, it is necessary to continuously improve the educational quality of curriculum ideological and political teachers, including the ability to explore, educate and evaluate the elements of ideological and political education in subject courses.

\subsection{Promote the Liveness, Context, and Curriculum of Ideological and Political Education Content}

For a long time, the "false, big, empty" content of ideological and political education has been difficult to respond to individual life experiences of college students, so it is difficult to stimulate emotional resonance in education and thus form a long-term education mechanism. In order to enhance the effectiveness of ideological and political education for college students, it is necessary to shift from "false, big and empty" content to "life-oriented, contextualized, and curriculum-oriented" one. To promote the ideological and political education of college students, we must insist that changing things according to the situation is the occasion for educating people, advancing from time to time is an opportunity to educate people, and everywhere is a place to educate people, and everyone can be a teacher for one another in different ways (Wang, 2017).

1) The life-oriented content of college students' ideological and political education

The content of ideological and political education for college students is to link the indirect ideological and political knowledge of grand narration with the personal life experience of college students and form the direct ideological and political knowledge of individual narrative that cares about the reality of life. The content of the life-oriented ideological and political education of college students reflects the in-depth grasp of the individual ideological and political quality of college students, the respect for the different life experiences of college students, and the objectification and concretization of abstract ideological and political knowledge. For example, setting up student party member workstations in college student apartments will enable ideological and political courses and curriculum ideological and political classes to communicate inside and outside the classroom, care about students' individual lives, and realize the organic connection between ideological and political education content and student life. 
2) Contextualization of the content of college students' ideological and political education

The contextualization of the content of ideological and political education for college students is to present ideological and political knowledge through real cases and activity scenes, so that the expression is more vivid. The contextualized content of ideological and political education for college students reflects the organic connection between ideological and political education and social reality and focuses on the internal logic and value core of knowledge generation. As a result, students learn to apply what they have learned and apply them flexibly, avoiding the boring content of ideological and political education. For example, the establishment of a student party member workstation in the college student apartment, relying on the daily real life of college students, organically integrates the content of ideological and political education, reflects the school-based, student-based, and contextual nature of the content, and realizes the activation of ideological and political knowledge.

3) Curricularization of ideological and political education for college students

The curricularization of the content of college students' ideological and political education is to construct its content system with goals, themes, and organization according to the logic of the course, the characteristics of ideological and political knowledge, the characteristics of college students' ideological and political literacy and the characteristics of their lives. Curriculum-based ideological and political education for college students establishes a long-term mechanism for education to make ideological and political education for college students orderly and effectively.

\subsection{Adopt Diversified Ideological and Political Education Methods That Are Experiential, Verifying, and Generative}

At present, the methods of college students' ideological and political education mostly adopt "giving-receiving", persuasive, and indoctrinating methods. As a result, students are in a state of passive learning, their participation in learning is not high, and the learning effect is sluggish. Studies have suggested that the innovation of ideological and political education for college students in the new era can be made from the following three dimensions: the down-to-earth popular dimension, the deep and thorough dimension, and the penetrating dimension ( $\mathrm{Wu}, 2018)$. Based on the content of ideological and political education of college students in life-orientation, contextualization, and curriculum, as well as the characteristics of the development of ideological and political quality of college students and the special stage of the critical period, in order to enhance the effectiveness of college students' ideological and political education, it is necessary to use experience, verification, generative, and diversified ideological and political education methods.

1) Experiential approach. The experiential method of ideological and political education for college students is a participatory teaching method of personal experience and perception in students' life scenes, such as student apartments, or 
in other real social education scenes, such as theme museums.

2) Confirmatory method. The verification method of college students' ideological and political education refers to the verification teaching method adopted by problem-oriented group project learning after classroom knowledge teaching. In this way, it reflects the dialectical view of education of the inner unity of "knowledge and action" in which the prophet goes after the action, and then proves in action.

3) A generative approach. The generative method of ideological and political education for college students refers to a kind of teaching that does not add any preset goals or advocates divergent thinking and brainstorming in the teaching of established goals and promotes the continuous expansion and deepening of the teaching process and effects means. For example, in the party building workstation activities in the college student apartment, students can regularly hold special events on ideological and political education for college students and adopt a generative approach to allow students to speak freely, stimulate thinking, and share ideas.

Through the investigation and analysis of the ideological and political quality of college students, a scientific and reasonable ideological and political education strategy system for college students has been constructed, which will promote the establishment of correct outlook on life, world view and values for college students. It will also encourage young students to exercise and grow in the great practice of building a moderately prosperous society in all respects as qualified socialist builders and reliable successors with grand ideals, moral integrity, professional expertise, and strict discipline.

\section{Conflicts of Interest}

The author declares no conflicts of interest regarding the publication of this paper.

\section{References}

Huang, W. H. (2020). Three Innovative Dimensions for Enhancing the Effectiveness of College Students' Ideological and Political Education in the New Period. Higher Education Forum, No. 1, 5-21.

Wang, H. L. (2017). Constructing an Ideological and Political "Four Comprehensive" Education System in Colleges and Universities. Ideological and Political Education Research, 33, 75-78.

Wu, Y. C. (2018). T A Probe into the Theory and Practice of Implementing the "Three Comprehensive Education" in Colleges and Universities in the New Era. China Higher Education, Z2, 35-37. 